Sains Malaysiana 50(11)(2021): 3263-3273

http://doi.org/10.17576/jsm-2021-5011-10

\title{
Hidrogel Berasaskan Pektin Kulit Buah Naga (Hylocereus polyrhizus) sebagai Pembawa Ubat melalui Sistem Penghantar Oral
}

(Pectin Based Hydrogel from Dragon Fruit Peels (Hylocereus polyrhizus) as Drug Carrier via Oral Delivery System)

\author{
AzWan Mat Lazim*, Farahain Mokhtar, Kalaivani Sanger, A. AzFaralariff, IzWan Ishak, I. Faiz

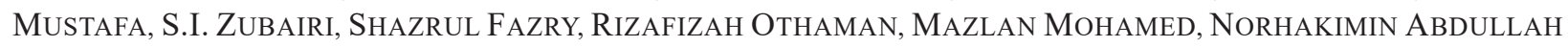 \\ \& H. HISHAM HAMZAH
}

ABSTRAK

Kajian ini memfokuskan kepada aplikasi hidrogel berasaskan ekstrak pektin daripada kulit buah naga (Hylocereus polyrhizus) yang digunakan sebagai biobahan pembawa ubat. Sebanyak 5 sampel telah disediakan dengan peratus komposisi pektin yang berbeza (0\%, 0.5\%, 1.0\%, 1.5\%, 2.0\%). Keputusan menunjukkan hidrogel dengan 1.0\% pektin telah mengembang secara maksimum pada pH 7. Imej daripada mikroskop elektron pengimbas (SEM) mendapati saiz keporosan hidrogel meningkat dengan penambahan pektin. Potensi hidrogel sebagai agen pembawa ubat telah dilakukan dengan melihat kecekapan muatan ubat, ujian perlepasan ubat dan ujian biodegradasi di dalam saluran pencernaan menggunakan medium simulasi perut (SGF), usus (SIF) dan kolon (SCF) secara in-vitro secara tanpa/ kehadiran enzim. Hasil ujian ketoksikan menggunakan kaedah embrio ikan kuda belang (Danio rerio) telah memberikan keputusan yang negatif terhadap hidrogel yang diuji.

Kata kunci: Hidrogel; oral; pektin; pembawa ubat

\section{ABSTRACT}

This study focused on the application of pectin based hydrogel extracted from pitaya peels (Hylocereus polyrhizus) as a biomaterial for drug carrier. Five different pectin extraction samples were prepared at a ratio of $0 \%$, 0.5\%, $1.0 \%, 1.5 \%$, and $2.0 \%$. Hydrogel with additional of $1.0 \%$ extracted pectin showed the best swelling performance at pH 7. Scanning electron microscope (SEM) images showed the porosity of hydrogel has increased by adding the pectin. The potential of hydrogel as drug delivery was evaluated by drug encapsulation efficiency and drug release profile tests in a simulated gastric fluid (SGF), simulated intestine fluid (SIF) and simulated colon fluid (SCF) without enzyme. In-vitro biodegradation tests were carried out using SGF, SIF and SCF in the presence of the enzyme showed degradation of sample due to decomposition of pectin by pectinase in the colon. The toxicity study using zebra fish embryo (Danio rerio) gave a negative result towards the hydrogel.

Keywords: Drug carrier; hydrogel; oral; pectin

\section{PENGENALAN}

Kaedah penyampaian secara oral adalah cara yang paling sesuai untuk menyampaikan ubat kepada bahagian sasaran kerana ia tidak memerlukan bantuan peralatan lain seperti jarum. Hal ini memudahkan bagi pesakit yang memerlukan pengambilan ubat setiap hari dan secara berjadual. Kaedah oral bukan sahaja selamat, tidak menyakitkan malah merupakan teknik mudah untuk dilakukan sendiri oleh pesakit. Namun begitu, sehingga kini penyampaian ubat secara oral ke kawasan gastrousus masih terhad terhadap beberapa ubat tertentu sahaja (Xu et al. 2015). Terdapat masih banyak ubat berasaskan protein dan peptida yang disampaikan ke dalam badan melalui kaedah jarum kerana masalah keberkesanan penyampaian ubat secara oral. Ini adalah disebabkan oleh keadaan asid yang terlalu tinggi ( $\mathrm{pH} \mathrm{1-2)} \mathrm{di} \mathrm{kawasan} \mathrm{perut} \mathrm{dan} \mathrm{usus}$ telah menjadi satu cabaran utama bagi melindungi ubat daripada terurai di kawasan tersebut. Selain itu didapati keberkesanan mekanisma perlepasan ubat di kawasan usus dan kolon menurun secara mendadak malah berkurang (Hamman et al. 2005; Vityazev et al. 2017).

Bagi mengatasi masalah penguraian berlaku terhadap pembawa ubat, hidrogel telah dipilih sebagai salah satu biobahan bagi menyampaikan ubat ke kawasan sasaran 
terutama kolon dan usus. Salah satu ciri istimewa hidrogel yang menjadi faktor utama ia digunakan secara meluas dalam bidang bioperubatan adalah kerana sifatnya yang lembut dan hampir menyerupai sel tisu manusia (Norhanisah \& Azwan 2017). Hidrogel bukan sahaja bertindak sebagai pembawa ubat, malah sebagai pelindung terhadap protein atau bahan aktif yang ingin disampaikan pada kawasan sasaran terutamanya di usus besar. Oleh kerana hidrogel bersifat responsif kepada perubahan keadaan sekeliling, maka ia boleh melepaskan ubat secara efektif pada keadaan pH yang berbeza, terutamanya pada saluran gastrousus (Nur Afiqah et al. 2020; Zhou et al. 2008).

Kebanyakan pelindung ubat bagi hidrogel diperbuat daripada bahan sintetik dan sukar terbiodegradasi. Oleh itu, penambahan biopolimer berasaskan sumber semula jadi membolehkan hidrogel mudah terbiodegradasi. Polisakarida seperti kanji, selulosa dan pektin telah diintegrasi bersama polimer sintetik seperti poli(asdi akrilik), poli(vinil pirimida) dan poli(akril amida) bagi menghasilkan hidrogel mudah terurai (Anekant et al. 2007). Kajian terdahulu telah melaporkan bahawa gabungan bahan sintetik dan biopolimer dapat menghasilkan hidrogel yang hijau, mudah terurai malah lebih efektif sebagai bahan pembawa dan perlepasan ubat (Gao et al. 2013; Prashant et al. 2008; Xu et al. 2015).

Salah satu biobahan yang diberi perhatian dalam penghantaran ubat adalah pektin bahan semula jadi ini mempunyai struktur fibre yang mudah ditemui di dinding sel utama dan antara lapisan sel tumbuhan terutama dalam buah-buahan (Abdullah et al. 2018). Pektin digunakan secara meluas sebagai biobahan dalam bidang bioperubatan kerana sifatnya yang tidak toksik, murah dari segi penghasilan dan mudah diperoleh. Selain itu sifatnya yang responsif terhadap $\mathrm{pH}$ dan kumpulan hidroksil yang mudah terion amat membantu dalam penghantaran ubat sasaran kolon (Deokar et al. 2016). Apa yang lebih menarik, kajian pektin sebagai penghantar ubat sasran kolon berasaskan ekstrak buah naga belum pernah dilaporkan oleh mana-mana penyelidik sebelum ini.

Berdasarkan maklumat tentang betapa pentingnya penyampai ubat berasaskan biobahan yang efektif, mudah terurai dan selamat maka, kajian ini telah memfokuskan kepada kesan penambahan ekstrak pektin daripada buah naga dalam penghasilan hidrogel. Keupayaannya untuk pengembangan, bertindak balas terhadap ransangan $\mathrm{pH}$ dan suhu, kekuatan mekanikal dan marfologi telah dicirikan bagi menentukan sifat hidrogel yang telah dihasilkan. Selain itu, keupayaan hidrogel sebagai agen penghantaran ubat, sifat terbiodegradasi dan ketoksikan turut dikaji bagi memastikan ia selamat untuk digunakan.

\section{METOD}

Bahan-bahan seperti asid hidroklorik, asid akrilik, ammonium persulfat, N,N'-metilena-bis-akrilamida (MERCK), larutan penimbal fosfat $\mathrm{pH} 7$, larutan penimbal fosfat $\mathrm{pH} 10$, natrium hidroksida, kalium dihidrogen fosfat, kalium hidrogen fosfat, kalium klorida (ALDRICH), enzim pankreatin, enzim pesin (SYSTERM) telah digunakan dalam kajian tanpa sebarang pemurnian dilakukan.

\section{PENGEKSTRAKAN PEKTIN}

Ekstrak pektin daripada kulit buah naga adalah berdasarkan kajian yang dilakukan oleh Tang et al. (2011) dengan sedikit perubahan. Didapati pengekstrakan yang dilakukan pada $\mathrm{pH} 3.5$ dalam tempoh 90 min memberikan hasil yang terbaik iaitu sebanyak $18.7 \%$.

\section{SINTESIS HIDROGEL BERASASKAN PEKTIN KULIT BUAH}

$$
\text { NAGA }
$$

Bagi mensintesis hidrogel berasaskan pektin, kaedah yang dilaporkan oleh Aidil Hakam et al. (2015) telah digunakan. Sebanyak $5 \mathrm{~mL}$ AA, $0.075 \pm 0.01 \mathrm{~g}$ MBA, 0.50 $\pm 0.05 \mathrm{~g}$ APS, $30 \mathrm{~mL}$ air suling dan pektin dimasukkan ke dalam bikar berisipadu $100 \mathrm{~mL}$. Larutan dipanaskan sehingga mencapai suhu $70{ }^{\circ} \mathrm{C}$ selama 15 minit sehingga larutan bertukar menjadi gel pepejal.

Hidrogel yang telah dihasilkan dicirikan menggunakan Spektroskopi Infra Merah Transformasi Fourier (FTIR/FT-NIR/Perkin Elmer-400) dan Mikroskopi Elektron Imbasan Pelbagai Tekanan (VPSEM) Leo, 1450VP. Manakala, ujian kekuatan regangan menggunakan mesin Universal Testometric model M350$10 \mathrm{kN}$ mengikut piawaian ASTM D412-68 menggunakan alat Hollow Die Punch dengan spesifikasi 6051/000.

\section{UJIAN FRAKSI GEL}

Hidrogel bersaiz $0.5 \mathrm{~cm} \times 0.5 \mathrm{~cm} \times 0.5 \mathrm{~cm}$ dikeringkan sepenuhnya pada suhu $37^{\circ} \mathrm{C}$ sehingga mencapai berat konsisten. Berat hidrogel dicatatkan sebagai $\mathrm{B}_{0}$. Gel kemudian diekstrak menggunakan air suling pada suhu bilik selama 7 hari. Berat akhir dicatat sebagai $B_{1}$. Peratus fraksi hidrogel dihitung menggunakan (1)

$$
\% \text { Fraksi gel }=\mathrm{B}_{0} / \mathrm{B}_{1} \times 100
$$


dengan $\mathrm{B}_{0}$ ialah berat hidrogel sebelum pengekstrakan dan $B_{1}$ ialah berat hidrogel selepas pengekstrakan.

\section{UJIAN PENGEMBANGAN PADA PH DAN SUHU BERBEZA}

Hidrogel bersaiz $0.5 \mathrm{~cm} \times 0.5 \mathrm{~cm} \times 0.5 \mathrm{~cm}$ ditimbang dan beratnya dicatat. Sampel dimasukkan ke dalam larutan penimbal berasid $(\mathrm{pH} \mathrm{1.2)}$, neutral $(\mathrm{pH} 7)$ dan alkali $(\mathrm{pH}$ 10) pada selang masa tertentu selama 24 jam. Peratus pengembangan hidrogel dalam larutan $\mathrm{pH}$ berbeza dicatatkan menggunakan (2).

$$
\% \text { Pengembangan }=\mathrm{M}_{0} / \mathrm{M}_{1} \times 100
$$

dengan $M_{0}$ berat hidrogel sebelum pengembangan dan $\mathrm{M}_{1}$ berat hidrogel selepas pengembangan.

\section{UJIAN KEUPAYAAN HIDROGEL SEBAGAI PEMBAWA UBAT}

Terdapat 3 uji kaji utama telah dilakukan iaitu ujian pengembangan dalam larutan simulasi perut (SGF), usus (SIF) dan kolon (SCF) adalah berdasarkan kajian yang telah dilakukan oleh Mohd Fadzlanor dan Azwani (2015). Seterusnya, ujian penjerapan ubat dan perlepasan ubat masing-masing adalah berdasarkan kajian yang dilakukan oleh Dan et al. (2013).

\section{UJI KAJI KETOKSIKAN DAN DEGRADASI}

Bagi menentusahkan bahawa hidrogel berasaskan pektin adalah selamat, ujan Ketoksikan Embrio Ikan (FET) telah dilakukan menggunakan prosedur OECD (OECD 2006). Manakala ujian degradasi adalah berdasarkan kajian yang dilakukan oleh Korsmeyer et al. (1983).

\section{KePUTUSAN DAN PERBINCANGAN}

FTIR

Rajah 1 menunjukkan spektra tiga komponen utama kajian iaitu asid akrilik (AA), ekstrak pektin daripada buah naga (Pc) dan hidrogel AA-pektin (AA-Pc). Proses cangkukan AA ke atas Pc boleh ditentukan dengan membandingkan spektrum hidrogel (AA-Pc) dengan spektrum asal bagi AA dan Pc. Puncak sekitar pada puncak 3200-3260 $\mathrm{cm}^{-1}$ mewakili regangan pada kumpulan hidroksil (O$\mathrm{H}), 1695 \mathrm{~cm}^{-1}$ mewakili regangan kumpulan berfungsi karbonil $(\mathrm{C}=\mathrm{O})$ manakala, puncak serapan pada 2913 $\mathrm{cm}^{-1}$ mewakili regangan kumpulan metil $(\mathrm{C}-\mathrm{H})$ pada $\mathrm{Pc}$ (Pavia et al. 2001). Didapati, berlaku pengurangan pada keamatan puncak bagi hidrogel (AA-Pc) pada $1025 \mathrm{~cm}^{-1}$ yang merujuk kepada regangan bagi kumpulan karbonil $(\mathrm{C}=\mathrm{O})$ pada kumpulan $\mathrm{CH}_{2} \mathrm{OH}$ berbanding dengan puncak pada $1015 \mathrm{~cm}^{-1}$ pada spektrum pektin. Menurut Zhou et al. (2008), perubahan ini telah menunjukkan bahawa berlaku tindak balas pempolimeran cangkukan pada kumpulan hidroksil primer pada pektin dan $\mathrm{C}=\mathrm{C}$ $\left(1600-1680 \mathrm{~cm}^{-1}\right)$ pada AA.

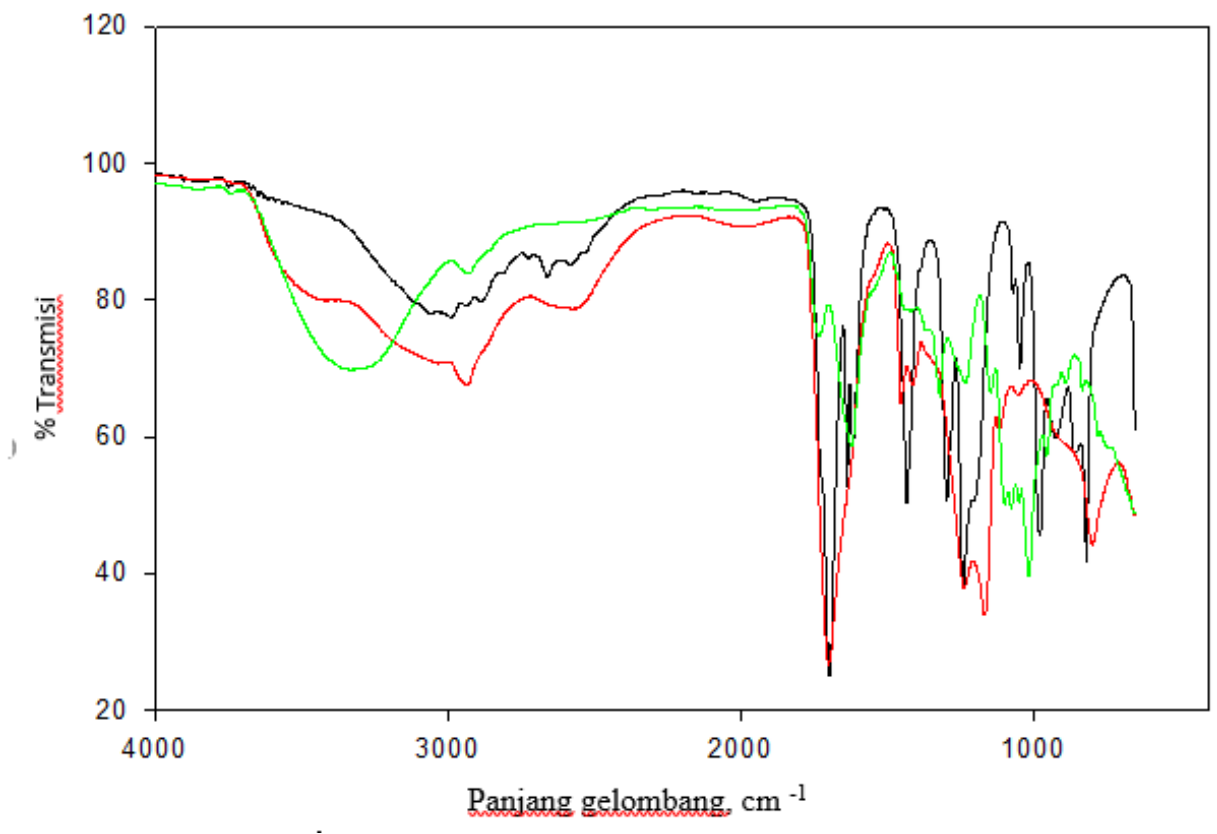

RAJAH 1. Spektra FTIR bagi asid akrilik (hitam), pektin (hijau) dan hidrogel AA-Pc (merah) 


\section{UJIAN FRAKSI GEL}

Ujian fraksi gel dilakukan bagi membuktikan hidrogel telah bertaut silang selepas proses pempolimeran (Hoffman et al. 2002). Fraksi gel menunjukkan jumlah pepejal yang tinggal selepas proses pengekstrakan hidrogel berlaku. Hidrogel yang tidak diekstrak menunjukkan proses pempolimeran daripada cecair kepada pepejal berjaya dihasilkan melalui proses pembentukan ikatan kovalen. Kekuatan ikatan polimer pada sistem hidrogel ditentukan oleh jumlah agen taut silang yang digunakan ketika proses pempolimeran berlaku. Jadual 1 menunjukkan keputusan ujian fraksi gel yang telah dijalankan dengan kandungan pektin yang berbeza iaitu $0.5 \%, 1.0 \%, 1.5 \%$ dan $2.0 \%$. Sebanyak $1.0 \%$ bahan pemula dan $1.5 \%$ agen taut silang digunakan untuk semua sampel. Didapati, jumlah peratusan fraksi gel berkurang dengan penambahan pektin. Keputusan ini menunjukkan pengurangan kekuatan ikatan taut silang telah berlaku. Oleh itu, hidrogel yang lebih kenyal dihasilkan. Hal ini dapat dibuktikan melalui ujian kekuatan regangan yang akan dibincangkan pada bahagian seterusnya.

JADUAL 1. Peratusan fraksi gel dengan penambahan pektin

\begin{tabular}{lccccc}
\hline $\begin{array}{l}\text { Penambahan } \\
\text { pektin }\end{array}$ & $0 \%$ & $0.5 \%$ & $1.0 \%$ & $1.5 \%$ & $2.0 \%$ \\
\hline & 94.7 & 93.4 & 91.5 & 91.3 & 90.4 \\
\hline
\end{tabular}

\section{UJIAN KEKUATAN REGANGAN HIDROGEL}

Ujian kekuatan regangan dijalankan untuk melihat pengaruh penambahan pektin terhadap tahap regangan hidrogel. Keputusan dicatatkan dalam Jadual 2 menunjukkan bahawa penambahan pektin telah meningkatkan kekuatan regangan hidrogel. Kekuatan regangan dengan penambahan pektin sebanyak $0.5 \%$ telah menunjukkan tahap regangan yang paling tinggi.
Penambahan lebih banyak pektin menyebabkan kekuatan regangan menurun. Hal ini disebabkan oleh pengurangan darjah taut silang di antara poli(asid akrilik) dan pektin. Penurunan fraksi gel ini menunjukkan ikatan taut silang yang semakin lemah akibat penambahan pektin (May 1990). Lebih banyak pektin yang ditambah menyebabkan lebih banyak agen taut silang diperlukan. Fenomena ini boleh dikaitkan dengan kandungan fraksi gel seperti yang telah dibincangkan sebelum ini.

JADUAL 2. Kekuatan regangan bagi sampel hidrogel berasaskan pektin kulit buah naga

\begin{tabular}{cc}
\hline $\begin{array}{c}\text { Peratus penambahan pektin } \\
(\%)\end{array}$ & $\begin{array}{c}\text { Kekuatan regangan } \\
(\mathrm{mm} / \mathrm{mm})\end{array}$ \\
\hline 0 & 0.74 \\
0.5 & 1.66 \\
1.0 & 1.49 \\
1.5 & 1.07 \\
2.0 & 0.93 \\
\hline
\end{tabular}

\section{UJIAN PENGEMBANGAN HIDROGEL DALAM MEDIUM $\mathrm{pH}$ BERBEZA}

Perbezaan keupayaan pengembangan hidrogel dalam medium $\mathrm{pH}$ yang berbeza dapat dilihat dengan jelas (Rajah 2). Secara umum, interaksi mula berlaku apabila kumpulan asid karboksilik - $\mathrm{COOH}$ pada jaringan poli(asid akrilik) dinyah proton membentuk $\mathrm{COO}^{-}$bercas negatif dengan kehadiran air. Ketidakseimbangan tekanan osmotik pada hidrogel dan medium persekitaran memaksa air untuk menyerap ke dalam jaringan hidrogel sehingga mencapai tahap keseimbangan. Namun dalam medium berasid, pengembangan tidak dapat berlaku kerana peneutralan 
cas negatif $\left(\mathrm{COO}^{-}\right)$dan cas positif $\left(\mathrm{H}^{+}\right)$berlaku. Didapati dengan penambahan pektin, peratus pengembangan hidrogel dalam medium berasid meningkat. Ini kerana kumpulan metoksi pada pektin terion membentuk $\mathrm{OH}^{-}$ yang bercas negatif. Kesan penolakan cas negatif antara pektin dan poli(asid akrilik) membolehkan pengembangan hidrogel berlaku. Namun, kepekatan ion $\mathrm{H}^{+}$yang tinggi dalam medium berasid ( $\mathrm{pH}$ 1.2) telah memberi rintangan yang cukup tinggi dan menghalang hidrogel daripada mengembang (Yoshii et al. 2003).

Dalam medium neutral, didapati hidrogel adalah bebas daripada rintangan medium. Ini membolehkan pengembangan berlaku tanpa halangan walaupun dibiarkan selama 24 jam, kerana proses tekanan osmotik berlaku sehingga mencapai tahap tekanan osmotik yang seimbang. Selain itu, didapati penambahan pektin telah meningkatkan pengembangan hidrogel sebanyak dua kali ganda berbanding hidrogel rujukan tanpa penambahan pektin. Tindak balas penolakan elektostatik di antara ion
$\mathrm{OH}^{-}$daripada kumpulan metoksi pektin dan poli(asid akrilik) telah menyebabkan pengembangan hidrogel berlaku hampir 3 kali ganda (3027\%) dengan penambahan $1.0 \%$ pektin. Namun begitu, berlaku penurunan kepada peratus pengembangan hidrogel apabila kandungan pektin ditambah. Perbezaan peratus pengembangan hidrogel adalah dipengaruhi oleh ketumpatan ko-polimer semasa proses pempolimeran. Penambahan pektin telah menyebabkan monomer asid akrilik cenderung untuk membentuk homopolimer dan mengganggu proses pempolimeran (Elliot et al. 2004).

Penurunan peratus pengembangan dalam medium alkali dengan penambahan pektin ke dalam poli(akrilik asid) adalah disebabkan oleh pengionan semula kumpulan asid karboksilik dan metoksi. Kumpulan cas negatif yang terdapat dalam medium persekitaran alkali dan cas negatif daripada hidrogel telah menyebabkan peneutralan cas berlaku dan menghalang proses pengembangan hidrogel (Ashri et al. 2018).

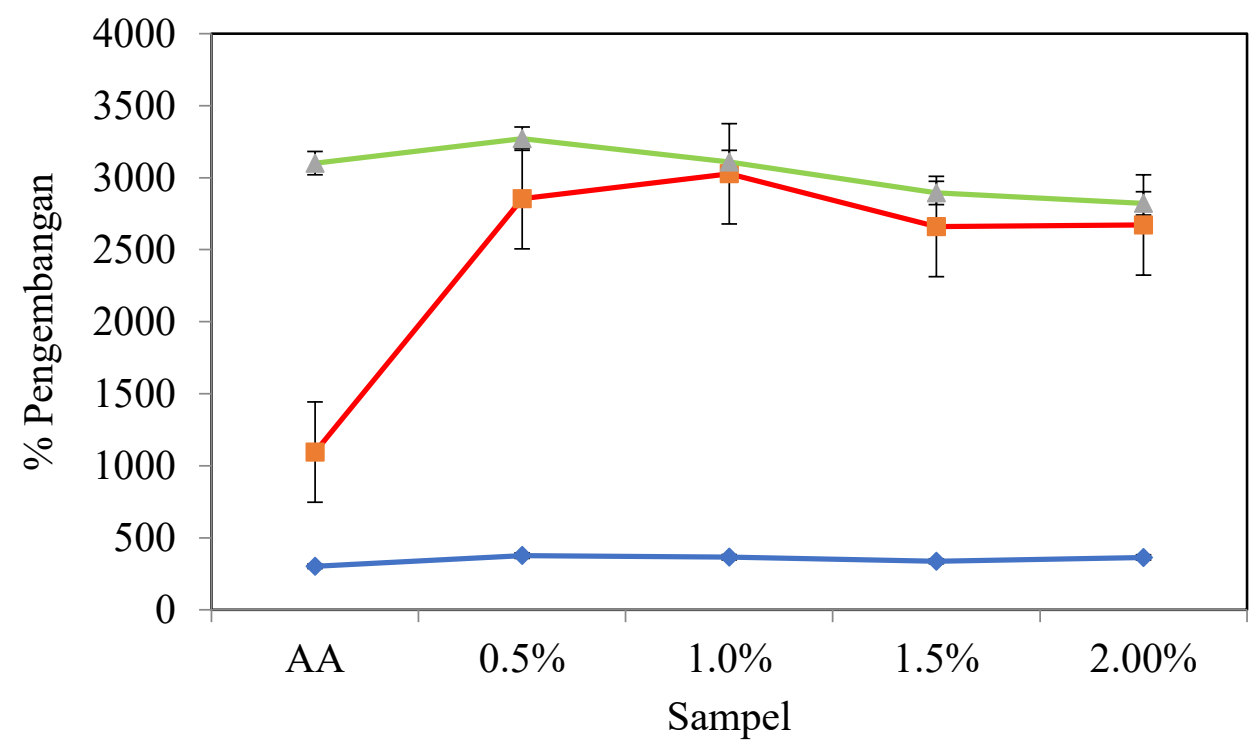

RAJAH 2. Graf peratus pengembangan melawan masa bagi AA, $0.5 \%, 1.0 \%, 1.5 \%$ dan $2.0 \%$ penambahan pektin pada $\mathrm{pH} 1.2$ (hijau), $\mathrm{pH} 7$ (merah) dan $\mathrm{pH} 10$ (biru)

\section{ANALISIS MARFOLOGI HIDROGEL}

Imej imbasan permukaan hidrogel bagi semua sampel selepas proses pengembangan dilakukan selama 24 jam telah diambil pada pembesaran 500x menggunakan Mikroskopi Imbasan Elektron(SEM). Rajah 3 menunjukkan poros yang terbentuk dalam medium neutral $(\mathrm{pH} 7)$ bagi hidrogel AA sebagai rujukan dan sampel dengan penambahan pektin sebanyak $0.5 \%, 1.0 \%, 1.5 \%$ dan $2.0 \%$. Keputusan telah menunjukkan terdapat liang poros terbentuk hasil penambahan pektin serta berkedut dan tidak padat pada imej yang diimbas. Pembentukan liangliang poros ini membantu dalam meningkatkan keupayaan hidrogel untuk mengembang. Ini kerana liang-liang ini memberi ruang bagi menyerapan air disebabkan oleh jaringan polimer hidrogel yang lemah. Turut diperhatikan, semakin banyak pektin ditambah, hidrogel menjadi kurang padat dan hal ini meningkatkan regangan hidrogel seperti yang dibincangkan sebelumnya. 

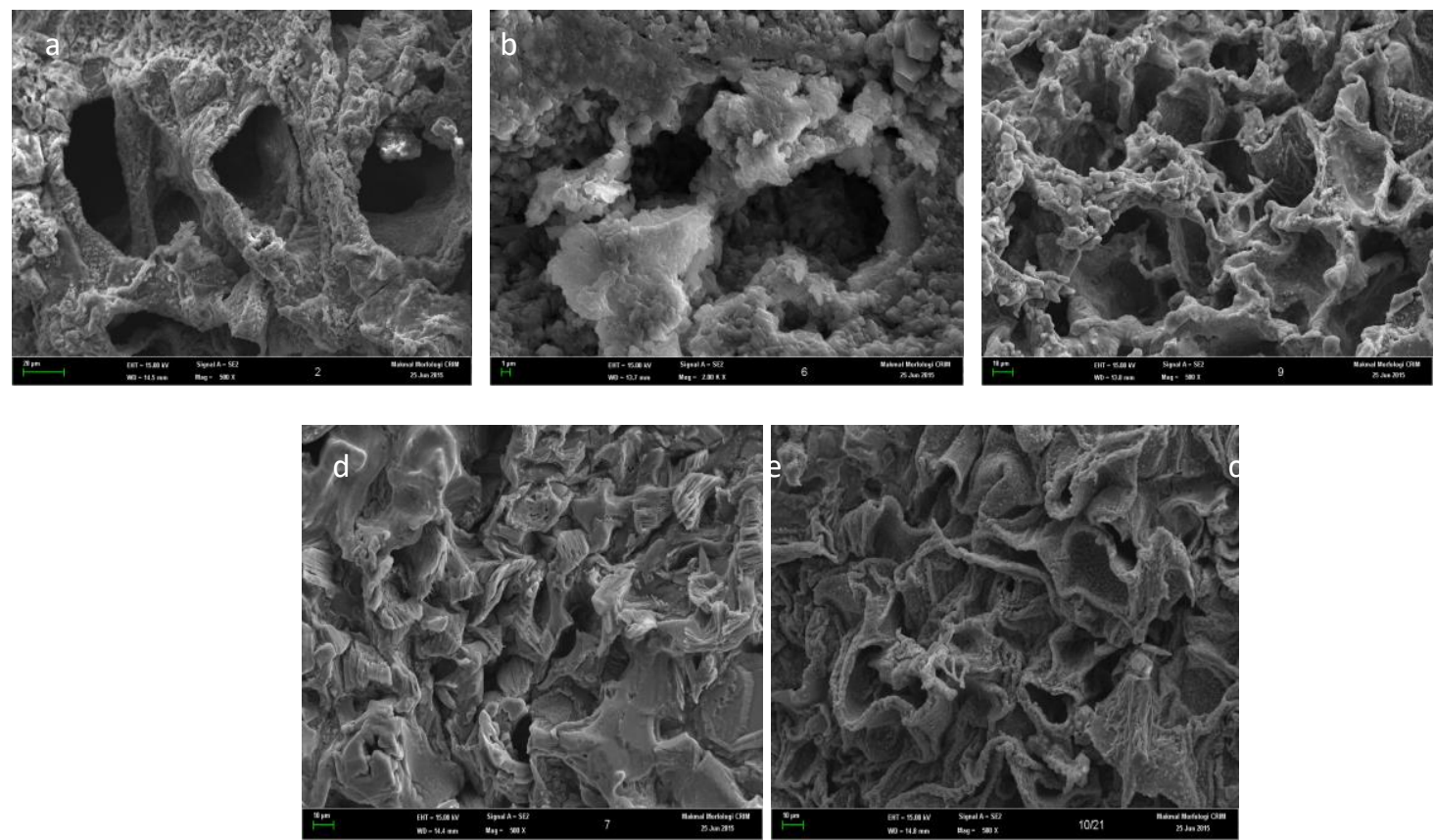

RAJAH 3. Keratan rentas hidrogel (a) AA, (b) $0.5 \%$, (c) $1.0 \%$, (d) $1.5 \%$, (e) $2.0 \%$ penambahan pektin pada $\mathrm{pH} 7$

\section{ANALISIS KEUPAYAAN HIDROGEL SEBAGAI AGEN PEMBAWA UBAT}

Ubat yang disampaikan melalui oral ke dalam badan akan melalui tiga bahagian utama iaitu perut, usus dan kolon. Namun begitu, cabaran utama penyampaian ubat melalui oral ialah perubahan $\mathrm{pH}$ yang melampau daripada perut ke usus. Selain itu, kehadiran enzim dan mikroflora boleh memusnahkan ubat. Oleh itu sekiranya ubat ingin disampaikan ke kawasan usus, ubat harus dilindungi daripada dicerna di kawasan perut. Ini kerana kawasan perut mempunyai $\mathrm{pH}$ 1.5-3.5 kemudian meningkat pada $\mathrm{pH}$ 5.5-7.1 pada kawasan usus dan kolon. Berikut adalah kajian yang telah dijalankan bagi tujuan melihat keupayaan hidrogel sebagai pembawa ubat.

\section{Ujian ketoksikan}

Ujian ketoksikan hidrogel dilakukan menggunakan kaedah embrio anak ikan kuda belang (FET). Hidrogel direndam dalam air suling pada suhu bilik selama 24 jam. Kesemua sampel disediakan pada kepekatan $30 \mathrm{uL} / \mathrm{mL}$. Hasil ekstrak air suling kemudian digunakan dalam ujian ini. Rajah 4 menunjukkan gambar embrio anak ikan kuda belang. Warna biru menggambarkan anak ikan masih hidup selepas 24, 48 dan 72 jam ujian dijalankan.

Ujian ketoksikan ini diuji untuk melihat tahap ketoksikan penggunaan $1.0 \%$ ammonium persulfat dan
$1.5 \%$ N,N-metil-bis-akrilamida. Penggunaan asid akrilik, ammonium persulfat dan $\mathrm{N}, \mathrm{N}$-metil-bis-akrilamida adalah malar dalam kajian ini. Keputusan telah menunjukkan peratus anak ikan masih hidup dalam setiap sampel dalam keseluruhan peratus embrio yang hidup adalah sebanyak $60 \%$ bagi penggunaan $1 \%$ ammonium persulfat dan $1.5 \% \mathrm{~N}, \mathrm{~N}$-metil-bis-akrilamida. Berdasarkan kajian Regina Sisika et al. (2019), adalah dicadangkan sekiranya $50 \%$ embrio ikan masih hidup, ia menunjukkan bahawa sampel yang digunakan masih selamat digunakan.

Ujian pengembangan hidrogel dalam simulasi perut (SGF), usus (SIF) dan kolon (SCF)

Ujian pengembangan di dalam larutan simulasi sistem gastrousus tanpa kehadiran enzim dilakukan untuk melihat potensi hidrogel berasaskan pektin kulit buah naga sebagai agen pembawa ubat merentasi sistem gastrousus manusia. Rajah 5 menunjukkan peratus pengembangan hidrogel dalam larutan simulasi perut (SGF), usus (SIF) dan kolon (SCF) pada suhu $37^{\circ} \mathrm{C}$ bagi semua sampel. Berdasarkan kajian awal yang telah dilakukan ke atas keupayaan hidrogel bertindak balas terhadap $\mathrm{pH}$, satu hipotesis awal telah diperoleh, iaitu hidrogel tidak mengembang di dalam medium berasid tetapi boleh mengembang pada $\mathrm{pH}$ 7. Seperti yang telah dijangkakan, keputusan kajian telah menunjukkan 
bahawa pengembangan semua sampel hidrogel adalah sangat rendah dalam larutan SGF ( $\mathrm{pH}$ 2). Manakala, hidrogel dengan penambahan pektin sebanyak 1.0\% memberikan peratus pengembagan tertinggi dalam medium simulasi usus ( $\mathrm{pH}$ 6.9) dan kolon ( $\mathrm{pH} 7.1$ ).

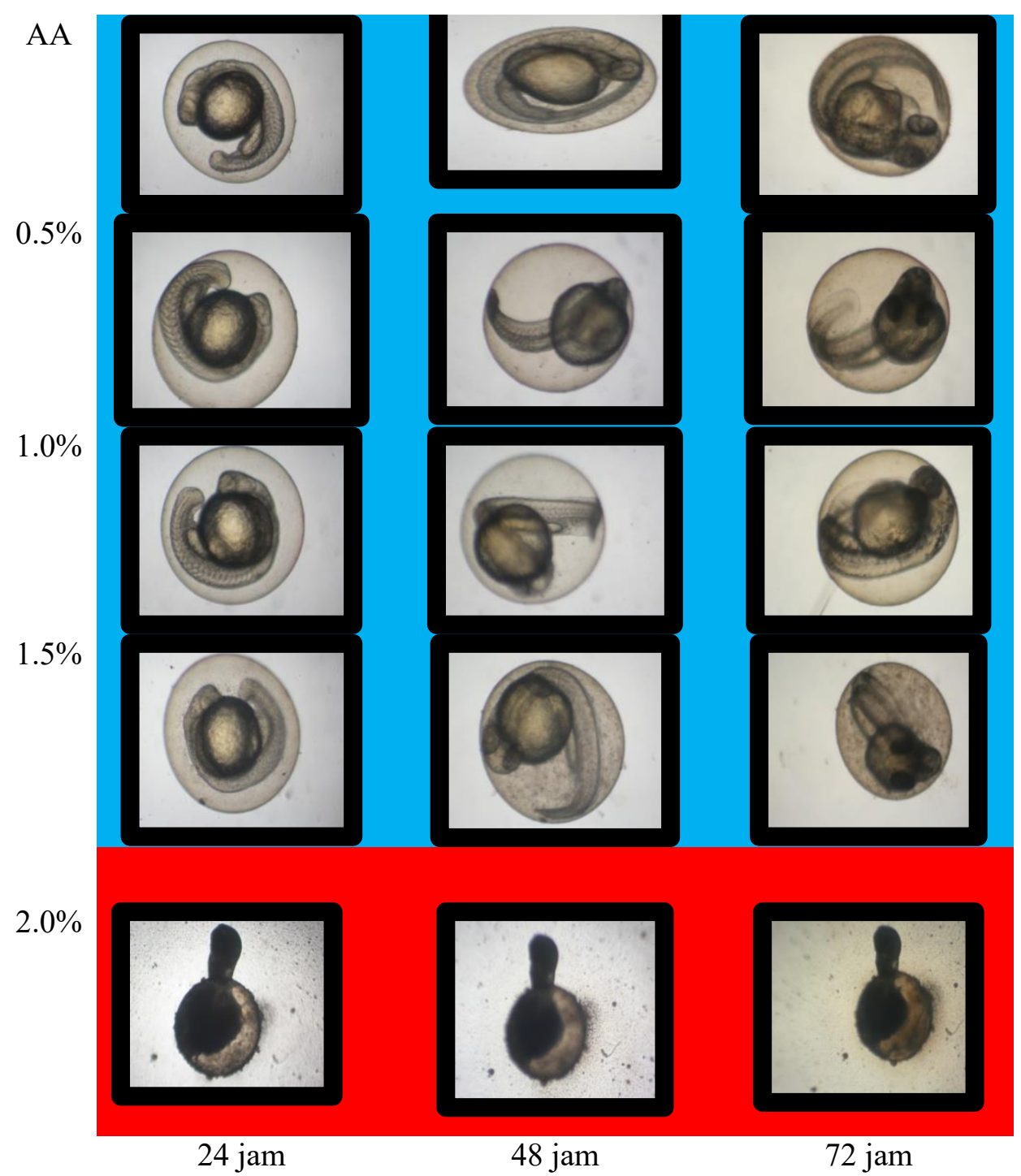

RAJAH 4. Imej mikroskop embrio ikan kuda belang dalam tempoh 72 jam

\section{UJIAN PENJERAPAN DAN PERLEPASAN UBAT}

Uji kaji ini telah dijalankan melalui kaedah penjerapan ubat. Oleh kerana hidrogel berasaskan pektin kulit buah naga adalah bersifat hidrofilik, maka ubat yang sesuai digunakan adalah ubat sodium asid diklofenak (Rajah 5(A)).

Rajah 5(B) menunjukkan hidrogel dengan pektin sebanyak $1.0 \%$ telah memberikan penjerapan yang paling efektif berbanding dengan sampel lain iaitu sebanyak 95.8\%. Pengembangan yang maksimum adalah dipengaruhi oleh saiz liang poros dan kuantiti yang banyak telah menyebabkan ubat dapat diserap secara maksimum ke dalam liang-liang hidrogel. Penjerapan ubat yang tersebar dalam matriks hidrogel ini dikenali sebagai sistem monolitik (Mizote et al. 1975).

Seterusnya, ujian lanjutan perlepasan ubat dilakukan di dalam larutan simulasi perut (SGF), usus (SIF) dan kolon (SCF) pada suhu $37^{\circ} \mathrm{C}$. Peratus perlepasan ubat berkadaran 
dengan masa telah diplotkan dalam graf pada Rajah 5(C). Keputusan telah menunjukkan tiada perlepasan ubat berlaku dalam larutan simulasi perut (SGF). Didapati kurang daripada $20 \%$ kandungan ubat dilepaskan dalam larutan simulasi usus (SIF) manakala sebanyak $55-77 \%$ ubat telah dilepaskan dalam larutan simulasi kolon (SCF). Selain daripada itu penambahan pektin pada setiap sampel telah menunjukkan peningkatan terhadap proses perlepasan ubat. Secara umum, mekanisma perlepasan ubat bermula apabila hidrogel mengembang. Pengembangan hidrogel disebabkan oleh penyerapan air akan menyebabkan liang hidrogel semakin membesar dan interaksi antara jaringan menjadi lemah, seterusnya keadaan ini membenarkan ubat melarut. Ubat yang bersifat hidrofilik akan menyerap air dan keluar daripada matriks hidrogel melalui proses osmosis akibat daripada perbezaan kepekatan. Kecerunan kepekatan dalam matriks hidrogel yang mengandungi ubat adalah lebih tinggi berbanding medium persekitaran akan memaksa ubat terlepas keluar daripada matriks hidrogel (Dan et al. 2013). Secara keseluruhannya, proses perlepasan ubat ini dikawal oleh proses penyerapan air masuk dan penyerapan ubat keluar daripada matriks hidrogel yang mengembang. Maka, kinetik perlepasan ubat mengikut semi-empirik Peppa yang mana ia sesuai digunakan untuk memahami kinetik perlepasan ubat (Korsmeyer et al. 1983). Persamaan $\mathrm{M}_{\mathrm{t}} / \mathrm{M}_{\infty}=\mathrm{kt}^{\mathrm{n}}$ telah digunakan, dengan $\mathrm{M}_{\mathrm{t}} / \mathrm{M}_{\infty}$ adalah perlepasan ubat pada masa, $t$. $k$ ialah pemalar sistem perlepasan ubat manakala $n$ adalah eksponen jerapan yang merujuk kepada mekanisma kinetik perlepasan ubat. Nilai $n$ dan $k$ dihitung berdasarkan lengkungan dan pintasan kepada graf yang diplot daripada persamaan $\ln \left(\mathrm{M}_{\mathrm{t}} / \mathrm{M}_{\infty}\right.$ $\leq 0.6)$ melawan $\ln \mathrm{t}$. Jadual 3 menunjukkan nilai $\mathrm{R}^{2}, k$ dan $n$ yang diperoleh daripada graf $\ln \left(\mathrm{M}_{\mathrm{t}} / \mathrm{M}_{\infty}\right)$ melawan ln $\mathrm{t}$ yang telah diplotkan. Tujuan penggunaan model matematik adalah untuk menerangkan secara ringkas proses perlepasan ubat yang rumit. Menurut undangundang Fickian, perlepasan melalui serapan keluar ubat daripada matriks hidrogel disebabkan oleh perbezaan kecerunan kepekatan ubat di dalam matriks hidrogel dan medium persekitarannya.
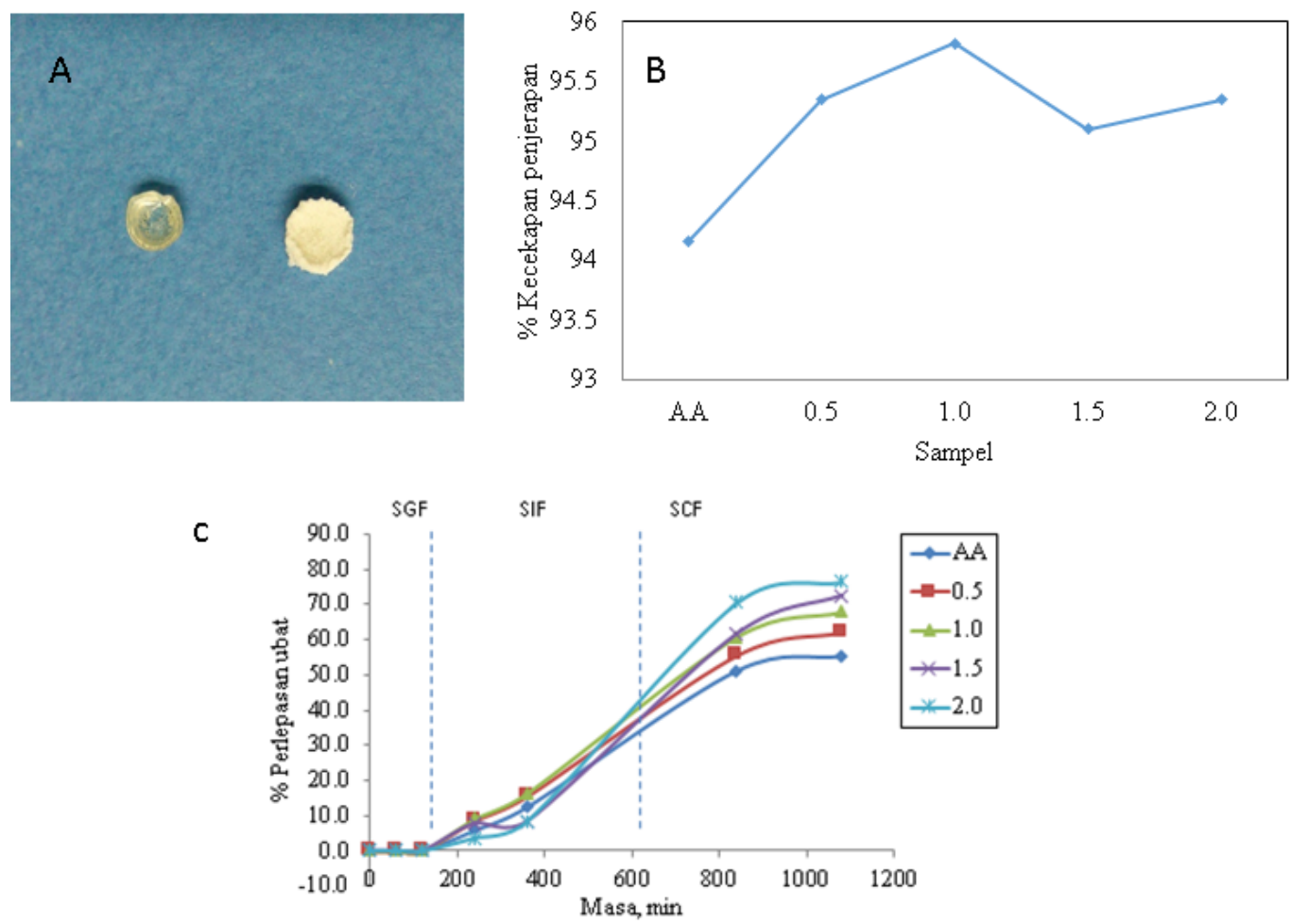

RAJAH 5. (A) Hidrogel sebelum (kiri) dan selepas (kanan) penjerapan sodium asid diklofenak, (B) Graf peratus kecekapan penjerapan ubat (\%EE) dan (C) Graf perlepasan ubat berkadaran dengan masa 
JADUAL 3. Nilai $\mathrm{R}^{2}$, $\mathrm{k}$ dan $\mathrm{n}$ untuk menentukan mekanisma perlepasan ubat

\begin{tabular}{ccccc}
\hline Sampel & $\mathrm{R}^{2}$ & $k$ & $n$ & Mekanisma perlepasan ubat \\
\hline AA & 0.91 & 0.45 & 0.35 & \\
0.5 & 0.92 & 0.64 & 0.31 & $n<0.5$ \\
1.0 & 0.92 & 0.66 & 0.32 & Serapan Fickian \\
1.5 & 0.84 & 0.42 & 0.38 & \\
2.0 & 0.90 & 0.08 & 0.49 & \\
\hline
\end{tabular}

\section{UJIAN DEGRADASI}

Ujian degradasi dilakukan dalam larutan simulasi perut (SGF), usus (SIF) dan kolon (SCF) dengan kehadiran enzim pepsin, pankreatin dan pektinase. Hidrogel direndam di dalam larutan simulasi selama 20 hari dan imej hidrogel dilihat melalui Mikroskopi Imbasan Elektron (SEM) pada pembesaran x 500 untuk melihat penguraian yang berlaku pada hidrogel seperti yang ditunjukkan pada Rajah 6.

Keputusan yang diperoleh telah menunjukkan bahawa hidrogel dalam larutan simulasi SGF pada $\mathrm{pH} 2$ dengan kehadiran enzim pepsin dan larutan simulasi SIF pada pH 6.9 dengan kehadiran enzim pankreatin tidak menunjukkan sebarang proses degradasi. Namun begitu, hidrogel dalam larutan simulasi SCF pada $\mathrm{pH} 7.1$ dengan kehadiran enzim pepsin telah menunjukkan proses degradasi berlaku. Penguraian ikatan kovalen pada struktur pektin oleh enzim pektinase berlaku akibat pemutusan ikatan pada C1 dan C4 rantaian asid galakturonik oleh enzim pektinase (Walter 1991).
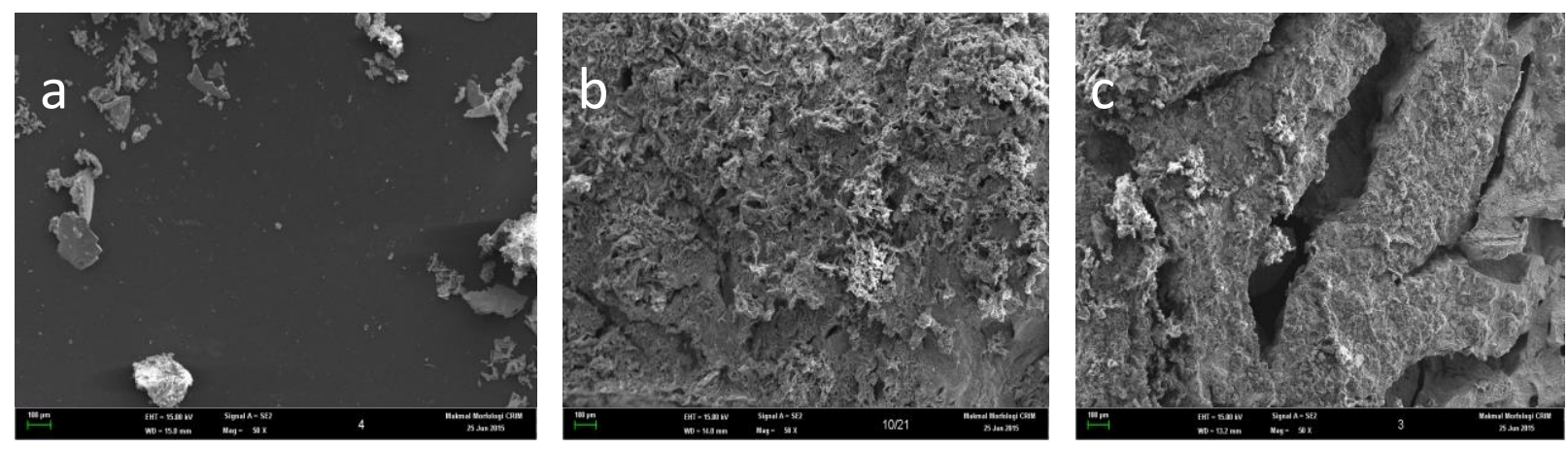

RAJAH 6. Imbasan SEM pada hari ke-20 pada sampel 1.0\% dalam a) SGF, b) SIF dan c) SCF

\section{KeSIMPULAN}

Kajian ini telah berjaya membuktikan keupayaan hidrogel berasaskan ekstrak pektin buah naga mampu bertindak sebagai biobahan penyampai ubat. Melalui ujian pengembangan dalam larutan simulasi perut, usus dan kolon, didapati hidrogel dengan kandungan pektin sebanyak $1.0 \%$ merupakan biobahan yang paling berpotensi untuk bertindak sebagai agen penghantaran ubat ke kawasan usus dan kolon. Mekanisma perlepasan ubat pada kawasan usus dan kolon mematuhi hukum serapan Fickian dengan perlepasan ubat berlaku kerana perbezaan kecerunan kepekatan ubat di dalam matriks hidrogel dengan medium persekitaran. Hidrogel dengan penambahan pektin juga menunjukkan kebolehannya terbiodegradasi di kawasan kolon. Oleh yang demikian, hidrogel berasaskan pektin buah naga amat berpotensi untuk diaplikasikan sebagai biobahan alternatif agen penyampai ubat ke kawasan usus dan kolon.

\section{PENGHARGAAN}

Penulis ingin merakamkan ucapan terima kasih kepada Universiti Kebangsaan Malaysia kerana membenarkan 
kajian ini dijalankan serta Kementerian Pengajian Tinggi atas geran (FRGS/1/2019/STG01/UKM/02/14).

\section{RUJUKAN}

Abdullah, M.F., Azfaralariff, A. \& Lazim, A.M. 2018. Methylene blue removal by using pectin-based hydrogels extracted from dragon fruit peel waste using gamma and microwave radiation polymerization techniques. Journal of Biomaterials Science, Polymer Edition 29(14): 17451763.

Adil Hakam, I. Abdul Rahman, M. Suzeren M. Jamil, Rizafizah Othaman, M.C.I. Mohamad Amin \& Azwan Mat Lazim. 2015. Removal of methylene blue dye in aqueous solution by sorption on a bacterialg-poly(acrylic acid) polymer network hydrogel. Sains Malaysiana 44(6): 827-834.

Airul Ashri, Nurul Amalina, Akhsan Kamil, Shazrul Fazry, M. Fareed Sairi, Muhammad Faizan Nazar \& Azwan Mat Lazim. 2018. Modified Dioscorea hispida starch-based hydrogels and their in-vitro cytotoxicity study on small intestine cell line (FHS-74 Int). International Journal of Biological Macromolecules 107(Part B): 2412-2421.

Anekant, J., Yashwant, G. \& Sanjay, K.J. 2007. Perspectives of biodegradable natural polysaccharides for site-specific drug delivery to the colon. J. Pharm. Pharmaceutical Sci. 10(1): 86-128.

Azwan Mat Lazim, Farahain Mokhtar, Siti Fairus Mohd Yusof, Ishak Ahmad \& Adil Hakam. 2013. Synthesis and characterization of ph sensitive hydrogel using extracted pectin from dragon fruit peel. Malaysian Journal of Analytical Sciences 17(3): 481-489.

Deokar, M.D., Idage, S.B., Idage, B.B. \& Sivaram, S. 2016. Synthesis and characterization of well-defined random and block copolymers of $\varepsilon$-caprolactone with 1-lactide as an additive for toughening polylactide: Influence of the molecular architecture. Journal of Applied Polymer Science 133(14).

Elliott, R., Greenberg, L.S. \& Lietaer, G. 2004. Research on experiential psychotherapies. In Bergin \& Garfield's Handbook of Psychotherapy and Behaviour Change. 5th ed., edited by Lambert, M.J. New York: Wiley. pp. 493-540.

Gao, X., He, C., Xiao, C., Zhuang, X. \& Chen, X. 2013. Biodegradable $\mathrm{pH}$ - responsive polyacrylic acid derivative hydrogels with tunable swelling behavior for oral delivery of insulin. Polymer 54(7): 1786-1793.

Hamman, J.H., Enslin, G.M. \& Kotze, A.F. 2005. Oral delivery of peptide drugs. BioDrugs 19: 165-177. https://doi. org/10.2165/00063030-200519030-00003.

Hoffman, A.S. 2002. Hydrogels for biomedical applications. Advanced Drug Delivery Reviews 43: 3-12.

Korsmeyer, R.W., Gurny, R., Doelker, E., Buri, P. \& Peppas, N.A. 1983. Mechanisms of solute release from porous hydrophilic polymers. International Journal of Pharmaceutics 15(1): 25-35.

May, C.D. 1990. Industrial pectin: Sources, production and applications. Carbohydrates Polymer 12: 79-99.
Mizote, A., Odagir, H., Toei, K. \& Tanaka, K. 1975. Determination of residues of carboxylic acids (mainly galacturonic acid) and their degree of esterification in industrial pectins by colloid titration with Cat-Floc. Analyst 100: 822-827.

Mohd Fadzlanor Abdullah \& Azwani Mat Lazim. 2017. Study on swelling behaviour of hydrogel based on acrylic acid and pectin from dragon fruit. AIP Conference Proceedings 1614: 492. doi: 10.1063/1.4895246.

Norhanisah Jamaludin \& Azwan Mat Lazim 2017. Sintesis dan pencirian hidrogel terbiodegradasi berasaskan bakteria selulosa menggunakan teknik radiasi ultra lembayung. Malaysian Journal of Analytical Sciences 21(5): 11111119.

Nur Afiqah Mustafa Kamal, Tuan Mazlelaa Tuan Mahmood, Ishak Ahmad \& Suria Ramli. 2020. Improving rate of gelatin/carboxymethylcellulose dissolving microneedle for transdermal drug delivery. Sains Malaysiana 49(9): 22692279 .

Pavia, D.L., Lampman, G.M. \& Kriz, G.S. 2001. Introduction to Spectroscopy. Boston: Thomson Learning, Inc.

Prashant B. Sutar, Rakesh K. Mishra, Kunal Pal \& Ajit K. Banthia. 2008. Development of $\mathrm{pH}$ sensitive polyacrylamide grafted pectin hydrogel for controlled drug delivery system. J. Mater. Sci: Mater. Med. 19: 2247-2253. https:// doi. org/10.1007/s10856-007-3162-y.

Regina Sisika, A. Sonthanasamy, Shazrul Fazry, Bohari M. Yamin \& Azwan Mat Lazim. 2019. Surface functionalization of highly luminescent carbon nanodots from Dioscorea hispida with polyethylene glycol and branced polyethyleneimine and their in vitro study. Journal of King Saud University - Science 31(4): 768-779.

Tang, P.Y., Wong, C.J. \& Woo, K.K. 2011. Optimization of pectin extraction from peel of dragon fruit (Hylocereus polyrhizus). Asian Journal of Biological Sciences 4(2): 189- 195

Vityazev, F.V., Fedyuneva, M.I., Golovchenko, V.V., Patova, O.A., Ipatova, E.U., Durnev, E.A., Martinson, E.A. \& Litvinets, S.G. 2017. Pectin-silica gels as matrices for controlled drug release in gastrointestinal tract. Carbohydrate Polymers 157: 9-20.

Walter, R.H. 1991. The Chemistry and Technology of Pectin. New York: Academic Press.

Xu, J., Strandman, S., Julian Zhu, X.X., Barralet, J. \& Cerruti, M. 2015. Genipin-crosslinked catechol-chitosan mucoadhesive hydrogels for buccal drug delivery. Biomaterial 37: 395 404.

Yoshii, F., Zhao, L., Wach, R.A., Nagasawa, N., Mitomo, H. \& Kume, T. 2003. Hydrogel of polysaccharide derivatives crosslinked with irradiation at paste-like condition. Nuclear Instruments and Methods in Physics Research (B) Beam Interactions with Materials \& Atoms 208: 320-324.

Zhou, Y., Yang, D., Chen, X., Xu, Q., Lu, F. \& Nie, J. 2008. Electrospun water-soluble carboxyethyl chitosan/poly(vinyl alcohol) nanofibrous membrane as potential wound dressing for skin regeneration. Biomacromolecules 9(1): 349-354. 
Azwan Mat Lazim*, Farahain Mokhtar, Kalaivani Sanger, A. Azfaralariff, Izwan Ishak, I. Faiz Mustafa, S.I. Zubairi, Shazrul Fazry \& Rizafizah Othaman

Fakulti Sains dan Teknologi

Universiti Kebangsaan Malaysia

43600 UKM Bangi, Selangor Darul Ehsan

Malaysia

Mazlan Mohamed \& Norhakimin Abdullah

Fakulti Biokejuruteraan dan Teknologi (FBET)

Universiti Malaysia Kelantan, Kampus Jeli

17600 Jeli, Kelantan Darul Naim

Malaysia
H. Hisham Hamzah

Pusat Pengajian Sains Kimia

Universiti Sains Malaysia

11800 Pulau Pinang

Malaysia

*Pengarang untuk surat-menyurat; email: azwanlazim@ukm. edu.my

Diserahkan: 21 Oktober 2020

Diterima: 4 Mac 2021 